subject and less experience of it at work. At this stage it is, I believe, more important that the student gains an understanding of the results of the mathematies than that he should be able to derive these results. In the former case, motivation for study of the mathematical details and methods can be established, while in the latter a barrier may be encountered which is never surmounted. A vital part of the understanding of the mathematical results lies in an appreciation of magnitudes when the symbols of the general case give way to the numbers of the particular. Any student can (or should be able to) substitute and evaluate an expression; unfortunately few will do so unless pressed and fewer still will make the immediate approximate calculations which can give the user the "feel" of a formula. The authors do not lose sight of the numerical aspect and many of their examples require calculation as well as algebraic manipulation. Of course, the examples are meant to illustrate the methods; perhaps the numbers are chosen nicely in order to avoid burdening those with less splendid and available automatic computing facilities than at Stanford. Should we not, however, be nearing the time when the embryo scientist ean be expected to have a basic knowledge of computer uso, ready access to a machine, as well as his grounding in mathematics? When we can assume this-and may it be soon in Britain-the numbers in problems can become realistic and with them the student's approach will become. closer to the practitioner's.

Nearly half of the book deals with mathomatical programming, introducing some network theory and applications, g ime theory and dynamic programming, as well as linear, integer and non-linear programming. About the same proportion of the book is devoted to probabilistic models-congestion, inventory, Markov chains and simulation-and a section giving preparation in probability and statisties which ean be omitted by those who do not need it. A welcome feature is the repcatcd questioning whether the model or analysis is appropriate, sometimes with vivid examples (for example, "tho result says, for example, that there should only be one rest room, albeit a large one, in the entire Pentagon! So what is wrong with model 3a?"). The mathematics is indubitable and inapplieable.

The book is long; a teacher may have a preference for minor changes in the contents and some will continue to seek satisfactory ways of obtaining and presenting problems in their raw, unformulated state, but the approach to the introductory toaching of operations research techniques will meet with the approval of many.

E. S. PAGE

\section{SOIL, A LIVING TISSUE}

Soil Biochemistry

Edited by A. D. MeLaren and G. H. Peterson. Pp. xiii + 509. (London: Edward Arnold (Publishers), Ltd.; New York: Marcel Dekker, Inc., 1967.) 180s. net.

There can be no doubt that the biochemistry of soil, whether of this world or the next, constitutes one of the inost important fields of research of today. This book provides an up to date review of the most outstanding aspects of terrestrial soil, its organisms and living constituents and their interactions. It also gives a brief and tantalizing guide for the assessing of possible organic constituents of the surface material of planets. Under the expert editorship of A. D. McLaren and G. H. Peterson, twenty-three international experts, mostly American, have written specialist chapters. The editors themselves provide an interesting introductory chapter of the biochemistry of terrestrial soils indicating the nature of soil constituents and processes and describing the interactions of living species associative and antagonistic in the soil. The book is divided into three parts: (1) the isolation and characterization of soil biochemicals; (2) the metabolism of soil biochemicals; and (3) relationships between soil and microbes. In the first part the organic substances dealt with are general nitrogenous compounds, nucleic acids, carbohydrates, organic acids and free radicals. There is little novelty among the various compounds beyond the fact that they are all clearly constituents of soil. The account of the stable free radicals, such as humic acid in the soil, is timely and interosting. Future studies using electron paramagnetic resonance on the complex soil macro-molecules may throw some light on their complex molecular structure.

The second part covers energy relationships, the biochemistry of the nitrogen cycle, organic sulphates and phosphates, lignin and humic acids and phenolic com. pounds. Two more important chapters describe the decomposition of herbicides and the degradation of detergents in soils. Concise descriptions are given of various soil enzymes.

The third part discusses the microbiological and biochemical aspects of the rhizosphere, which is the zone of soil in which plant roots exert their influence. All the chapters are written clearly and in great detail, providing a wealth of information with full references. The book will prove of the greatest value to advanced students and to all chemists and biologists. M. StaCeY

\section{TEMPERATURE MEASUREMENT}

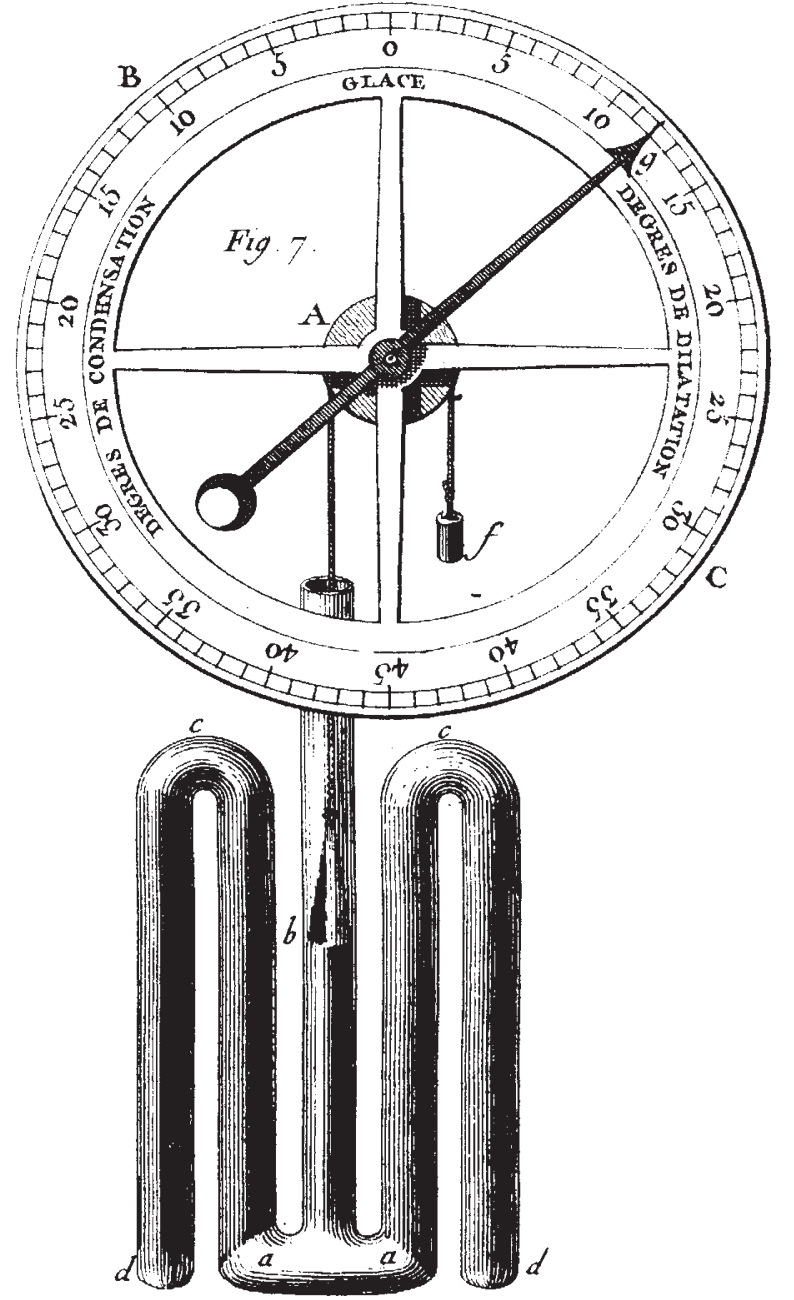

Berthond's dial thermometer, 1763. From A History of the Thermometer and its Uses in Meteorology, by W. E. Knowles Middleton. (Johns Hopkins Press; Oxford University Press; 80s.) 